Karmawibangga : Historical Studies Journal, Vol: 01, No: 01, 2019: 26-32

ISSN:- E-ISSN:

htpps://journal.upy.ac.id/index.php/karmawibangga

\title{
PENINGKATAN NILAI SEJARAH DENGAN MODEL SNOWBALL THROWING DI KELAS XI-IIS SMA MUHAMMADIYAH 2 YOGYAKARTA
}

\author{
Oleh : Sariyana \\ Guru Sejarah SMA Muhammadiyah 2 Yogyakarta \\ sariyana017@gmail.com
}

\begin{abstract}
Abstrak
Penelitian ini merupakan penelitian tindakan kelas yang terdiri atas 2 siklus dengan subjek penelitian adalah peserta didik kelas XI Ilmu Ilmu Sosial yang berjumlah 36 peserta didik tahun pelajaran 2016/2017. Data dikumpulkan dengan tes kemampuan meningkatkan prestasi belajar, dan lembar observasi aktifitas siswa. Analisis data menggunakan analisis deskriptif kualitatif dan kuantitatif.

Berdasarkan hasil penelitian pertemuan pertama siklus I peserta didik yang dinyatakan tuntas adalah $12 \%$, ratarata nilai 76,67. Pertemuan kedua siklus I peserta didik yang dinyatakan tuntas adalah 55\%, dengan rata-rata nilai 87,10. Hasil belajar meningkat $43 \%$. Sedangkan kemampuan memecahkan masalah pertemuan pertama siklus II adalah $47 \%$ dengan rata-rata nilai 83,75 . Pada pertemuan kedua siklus II diperoleh $81 \%$ dengan rata-rata nilai 93,23. Sehingga hasil belajar meningkat $34 \%$. Hasil penelitian menunjukkan bahwa pembelajaran menggunakan model Snowball Throwing dapat meningkatkan nilai belajar sejarah peserta didik kelas XI IIS-2 SMA Muhammadiyah 2 Yogyakarta.
\end{abstract}

Kata kunci: Model Sowball Throwing, prestasi belajar

\begin{abstract}
This research is a classroom action research consisting of 2 cycles with the research subject being 36th grade students of the Social Sciences Sciences in the academic year 2016/2017. Data was collected by the ability test to improve learning achievement, and student activity observation sheets. Data analysis used qualitative and quantitative descriptive analysis.

Based on the results of the first cycle I research, students who were declared complete were $12 \%$, averaging 76.67. The second meeting of the first cycle of students who were declared complete was $55 \%$, with an average score of 87.10. Learning outcomes increased by $43 \%$. While the problem solving ability of the first meeting of the second cycle was $47 \%$ with an average value of 83.75. At the second meeting the second cycle was obtained $81 \%$ with an average value of 93.23. So that learning outcomes increase $34 \%$. The results of the study show that learning using the Snowball Throwing model can increase the learning value of history of class XI IIS-2 students of Muhammadiyah 2 High School Yogyakarta
\end{abstract}

Keyword : Sowball Throwing model, learning achievement 


\section{PENDAHULUAN}

Belajar ialah proses usaha yang dilakukan seseorang untuk memperoleh suatu perubahan tingkah laku yang baru secara keseluruhan, sebagai hasil pengalamanya sendiri dalam interaksi dengan lingkungannya (Slamet, 2003:57). Perubahan dalam sistem pendidikan disebabkan oleh adanya pembaharuan-pembaharuan yang dapat memicu pendidikan di sekolah-sekolah banyak mengalami kemajuan yang sangat pesat sehingga dalam pembelajaran guru cenderung ingin menemukan model pembelajaran yang dapat memotivasi semangat belajar siswa.

Mata pelajaran Sejarah dianggap paling mudah oleh kebanyakan orang karena pelajarannya identik dengan hafalan, angka tahun dan mencatat sehingga para guru khususnya guru mata pelajaran Sejarah memiliki beban atau tantangan tersendiri untuk dapat mencari suatu model pembelajaran yang menarik dan dapat menciptakan suasana senang sehingga siswa tidak merasa bosan dalam mengikuti mata pelajaran Sejarah. Model pembelajaran yang dipilih tentu tidak sulit untuk diterapkan oleh guru sehingga nilai hasil belajar siswa terhadap mata pelajaran Sejarah di sekolah-sekolah dapat meningkat. Nilai merujuk pada prestasi, sedangkan prestasi belajar itu merupakan indikator adanya dan derajat perubahan tingkah laku siswa (Hamalik, 2011:159).

Pengertian Model Pembelajaran dapat diartikan sebagai cara, contoh maupun pola, yang mempunyai tujuan menyajikan pesan kepada siswa yang harus diketahui, dimengerti, dan dipahami yaitu dengan cara membuat suatu pola atau contoh dengan bahanbahan yang dipilih oleh para pendidik atau guru sesuai dengan materi yang diberikan dan kondisi di dalam kelas. Suatu model akan mempunyai ciri-ciri tertentu dilihat dari faktor-faktor yang melengkapinya. Jadi model pembelajaran adalah sebuah sistem proses pembelajaran yang utuh, mulai dari awal hingga akhir. Berdasarkan teori-teori belajar dapat ditentukan beberapa pendekatan pembelajaran, dan berdasarkan pendekatan tadi dapat ditentukan menjadi empat model utama dalam pembelajaran salah satu diantaranya adalah Model Interaksi Sosial (Hamalik, 2011:127). Model pembelajaran merupakan cara atau teknik penyajian yang digunakan guru dalam proses pembelajaran agar tercapai tujuan pembelajaran. Ada beberapa model-model pembelajaran seperti Snowball Throwing, ceramah, diskusi, demonstrasi, studi kasus, bermain peran (role play) dan lain sebagainya. Masingmasing model pembelajaran tentunya memiliki kelemahan dan kelebihan. Metode atau model sangat penting peranannya dalam pembelajaran, karena melalui pemilihan model atau metode yang tepat dapat mengarahkan guru pada kualitas pembelajaran efektif.

$$
\text { Kondisi nyata kegiatan }
$$
pembelajaran mata pelajaran Sejarah di kelas XI IIS-2 SMA Muhammadiyah 2 Yogyakarta belum menemukan model pembelajaran yang tepat, sehingga peserta didik masih banyak kesulitan untuk memahami materi mata pelajaran Sejarah dan nilai hasil belajar banyak yang belum tuntas.

Peneliti setelah berdiskusi dengan kolaborator akhirnya diperoleh kesepakatan bahwa model Snowball Throwing dianggap sebagai salah satu cara yang sangat cocok digunakan sebagai upaya untuk meningkatkan nilai belajar mata pelajaran Sejarah Indonesia siswa kelas XI IIS-2 SMA Muhammadiyah 2 Yogyakarta tahun pelajaran 2016-2017. Snowball Throwing berasal dari dua kata yaitu "Snowball" dan "Throwing". Kata 
snowball berarti bola salju, sedangkan Throwing berarti melempar, jadi Snowball Throwing adalah melempar bola salju. Pembelajaran Snowball Throwing adalah suatu model pembelajaran yang membagi murid dalam beberapa kelompok, yang nantinya masing-masing anggota kelompok membuat sebuah pertanyaan pada selembar kertas dan membentuknya seperti bola, kemudian bola tersebut dilempar ke murid yang lain selama durasi waktu yang ditentukan, selanjutnya masing-masing murid menjawab pertanyaan dari bola yang diperolehnya. Pelaksanaan model Snowball Throwing ini memiliki kelebihan yaitu:

1. Pembelajaran model Snowball Throwing terdapat unsur permainan yang dapat menarik perhatian dan keaktifan siswa,

2. Mampu melatih kesiapan siswa dalam merumuskan pertanyaanpertanyaan,

3. Mampu menumbuhkan kerjasama dan saling memberikan pengetahuan,

4. Siswa akan terus termotivasi untuk meningkatkan kemampuan sehingga mampu meningkatkan nilai mata pelajaran Sejarah.

\section{METODE PENELITIAN}

Penelitian ini merupakan penelitian tindakan kelas yang dilaksanakan di SMA Muhammadiyah 2 Yogyakarta pada semester ganjil tahun pelajaran 2016-2017. Kegiatan penelitian selama 4 bulan Juli sampai Oktober 2016, Seminar hasil penelitian awal Nopember 2016.

Subyek penelitian tindakan kelas di SMA Muhammadiyah 2 Yogyakarta terlalu luas poulasinya. Untuk itu peneliti mengambil sampel subyek penelitian ini adalah siswa kelas XI IIS2 SMA Muhammadiyah 2 Yogyakarta tahun pelajaran 2016-2017 yang berjumlah 36 siswa. Teknik pengumpulan data dalam penelitian ini menggunakan metode observasi, tes tertulis, wawancara dan catatan lapangan. Setelah data terkumpul lalu dilakukan analisis data secara deskriptif persentase kuantitatif dan kualitatif. Data kualitatif yang didapat kemudian dilakukan analisis dan dideskripsikan hasilnya. Demikian halnya dengan data kuantitatif setelah dihitung hasilnya kemudian dianalisis persentase, selanjutnya dideskripsikan kedalam uraian kalimat yang jelas.

Data lain sebagai pendukung penelitian adalah lembar observasi dan skala penilaian terhadap siswadidalam performance dan keaktifan dalam diskusi, Tanya jawab serta catatan lapangan yang hasilnya akan dideskripsikan secara kualitatif. Adapun analisis data perlu memperhatikan beberapa hal, sebagai berikut: inteprestasi tidak melenceng dari hasil analisis, interprestasi harus harus dalam batas kerangka penelitian, dan secara etis peneliti rela mengemukakan kesulitan dan hambatan-hambatan sewaktu dalam penelitian (Riduwan, 2010:108)

Berdasarkan pengamatan peneliti sampel penelitian tersebut sudah diambil dari populasi yang betul-betul representatif (Sugiyono, 2010:118). Prosedur penelitian menggunakan desain model penelitian yang dikembangkan oleh (Suharsimi, 2012:16).

Gambar 1 Siklus Penelitian Tindakan Kelas (Suharsimi, 2012:16)

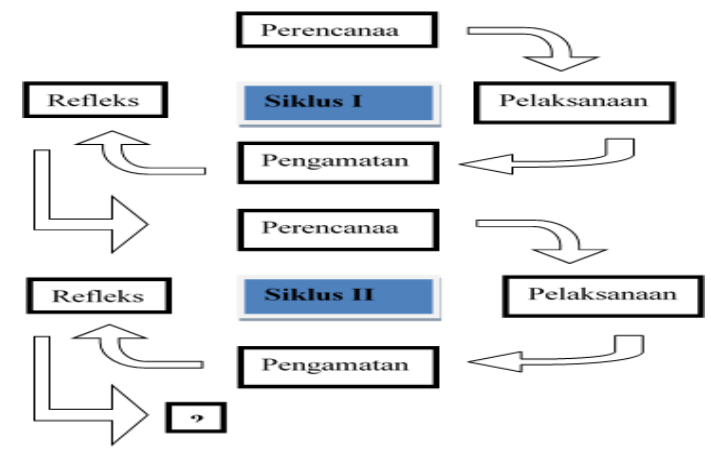




\section{Hasil dan Pembahasan}

\section{Deskripsi Siklus I Pertemuan Pertama}

Siklus I Pertemuan pertama dilaksanakan pada hari Selasa, 27 September 2016 pada jam ke 7 dan jam ke 8 selama 90 menit atau dari jam 12.30 sampai 14.00 WIB di kelas XI IIS 2 SMA Muhammadiyah 2 Yogyakarta siswa seharusnya berjumlah 36 orang tetapi karena ada 3 orang yang tidak hadir jadi hanya 33 orang. Adapun kompetensi dasar menganalisis sistem pemerintahan, sosial, ekonomi, dan kebudayaan masyarakat Indonesia pada masa kerajaan-kerajaan besar Islam di Indonesia yang berpengaruh pada kehidupan masyarakat Indonesia masa kini dan materi pelajaran menganalisis kehidupan politik-pemerintahan pada masa Kerajaan Islam di Indonesia.

Berdasarkan aktifitas siswa yang diamati sesuai dengan keterlibatan siswa selama proses pembelajaran pada pertemuan pertama Siklus I di atas, sebagai berikut:

a. Keaktifan siswa mendengarkan penjelasan guru $73 \%$, berpredikat cukup, sehingga perlu ditingkatkan.

b. Keaktifan siswa aktif dalam pembelajaran $82 \%$ dan bekerjasama dengan baik dalam kegiatan kelompok $\quad 85 \% \quad$ keduanya berpredikat baik, sehingga perlu dipertahankan dan ditingkatkan.

c. Keaktifan peserta berani mengemukakan pendapat $27 \%$ dan merespon pertanyaan dari guru 39\% berpredikat kurang, sehingga perlu perhatian khusus untuk pembiasaan dan motivasi.

Peneliti perlu berkolaborasi dengan guru sebagai kolaborator dalam penelitian ini untuk mendiskusikan kekurangan-kekurangan saat proses belajar mengajar yang telah dilakukan. Hal ini bertujuan untuk memperbaiki proses belajar mengajar selanjutnya.
Hasil uji kompetensi dengan penetapan Kriteria Ketuntasan Minimal (KKM) 75 pada siklus I pertemuan pertama yang diikuti oleh 33 siswa ternyata hasilnya sangat memprehatinkan karena yang tidak tuntas ada 29 siswa dan 4 siswa tuntas, sehingga ketuntasan belajar siswa pada siklus I pertemuan pertama adalah $12 \%$ dengan nilai rata-rata kelas 76,67 . Dengan demikian perlu adanya suatu tindakan untuk meningkatkan ketuntasan atau prestasi belajar.

\section{Deskripsi Siklus I Pertemuan Kedua}

Pertemuan kedua Siklus I dilaksanakan pada hari Sabtu, 1 Oktober 2016 pada jam ke-3 dan 4 atau pukul 08.30 sampai $10.00 \mathrm{WIB}$, di kelas XI IIS 2 SMA Muhammadiyah 2 Yogyakarta siswa seharusnya berjumlah 36 siswa tetapi ada 5 siswa yang tidak hadir jadi hanya 31 peserta didik. Berdasarkan hasil penelitian yang telah dilaksanakan pada siklus I pertemuan kedua yang sangat memprehatinkan dengan tingkat ketuntasan $12 \%$ dari KKM 75, maka perlu adanya strategi yang tepat dan akurat dalam proses pembelajaran menerapkan model Snowball Throwing. Kompetensi dasar menganalisis sistem pemerintahan, sosial, ekonomi, dan kebudayaan masyarakat Indonesia pada masa kerajaan-kerajaan besar Islam di Indonesia yang berpengaruh pada kehidupan masyarakat Indonesia masa kini dan materi pelajaran menganalisis kehidupan politik-pemerintahan pada masa Kerajaan Islam di Indonesia.

Berdasarkan aktifitas siswa yang diamati sesuai dengan keterlibatan siswa selama proses pembelajaran pada siklus I pertemuan kedua di atas, sebagai berikut:

a. Keaktifan siswa mendengarkan penjelasan guru $84 \%$, merespon pertanyaan dari guru $81 \%$, keduanya 
berpredikat baik, sehingga perlu ditingkatkan.

b. Keaktifan siswa aktif dalam pembelajaran $90 \%$ dan bekerjasama dengan baik dalam kegiatan kelompok 97\%, keduanya berpredikat amat baik, sehingga perlu dipertahankan dan ditingkatkan.

c. Keaktifan peserta berani mengemukakan pendapat $55 \%$, berpredikat kurang, sehingga perlu perhatian khusus untuk pembiasaan dan motivasi.

Hasil uji kompetensi dengan penetapan Kriteria Ketuntasan Minimal (KKM) 75 pada siklus I pertemuan kedua yang diikuti oleh 31 siswa ternyata hasilnya masih sangat perlu ditingkatkan karena yang tidak tuntas ada 14 siswa dan 17 siswa tuntas, sehingga ketuntasan belajar siswa pada pertemuan kedua siklus I adalah $55 \%$ dengan rata-rata nilai kelas 87,10. Dengan demikian meskipun sudah ada peningkatan $43 \%$ dari siklus I pertemuan pertama tetapi masih perlu adanya suatu tindakan untuk meningkatkan ketuntasan atau prestasi belajar.

\section{Deskripsi Siklus II Pertemuan Pertama}

Pelaksanaan siklus II Pertemuan pertama pada hari Selasa, 25 Oktober 2016 pada jam ke 7 dan jam ke 8 selama 90 menit atau dari jam 12.30 sampai 14.00 WIB di kelas XI IIS 2 SMA Muhammadiyah 2 Yogyakarta siswa seharusnya berjumlah 36 siswa tetapi karena ada 4 siswa yang tidak hadir jadi hanya 32 peserta didik. Adapun kompetensi dasar menganalisis sistem pemerintahan, sosial, ekonomi, dan kebudayaan masyarakat Indonesia pada masa kerajaan-kerajaan besar Islam di Indonesia yang berpengaruh pada kehidupan masyarakat Indonesia masa kini dan materi pelajaran menganalisis kehidupan sosial, ekonomi pada masa Kerajaan Islam di Indonesia.

Berdasarkan aktifitas siswa yang diamati sesuai dengan keterlibatan siswa selama proses pembelajaran pada pertemuan pertama siklus II di atas, sebagai berikut:

a. Keaktifan siswa mendengarkan penjelasan guru $81 \%$, dan aktif dalam pembelajaran $84 \%$, keduanya berpredikat baik, sehingga perlu ditingkatkan.

b. Keaktifan peserta berani mengemukakan pendapat $72 \%$ dan merespon pertanyaan dari guru $78 \%$, keduanya berpredikat cukup, sehingga perlu perhatian khusus dan motivasi.

c. Keaktifan siswa bekerjasama dengan baik dalam kegiatan kelompok 91\%, berpredikat amat baik, sehingga perlu dipertahankan dan ditingkatkan.

Hasil uji kompetensi dengan penetapan Kriteria Ketuntasan Minimal (KKM) 75 pada pertemuan pertama siklus II yang diikuti oleh 32 siswa ternyata hasilnya masih perlu ditingkatkan karena yang tidak tuntas ada 17 siswa dan 15 siswa tuntas, sehingga ketuntasan belajar siswa pada siklus II pertemuan pertama adalah $47 \%$ dengan rata-rata nilai kelas 83,75. Dengan demikian perlu adanya suatu tindakan untuk meningkatkan ketuntasan atau prestasi belajar.

\section{Deskripsi Siklus II Pertemuan Kedua}

Pelaksanaan siklus II pertemuan kedua pada hari Sabtu, 29 Oktober 2016 pada jam ke-3 dan 4 atau pukul 08.30 samapai 10.00 WIB, di kelas XI IIS 2 SMA Muhammadiyah 2 Yogyakarta siswa seharusnya berjumlah 36 siswa tetapi ada 5 siswa yang tidak hadir jadi hanya 31 peserta didik. Berdasarkan hasil penelitian yang telah dilaksanakan pada pertemuan pertama siklus II dengan 
tingkat ketuntasan $47 \%$ dari KKM 75, maka perlu adanya strategi yang tepat dan akurat dalam proses pembelajaran menerapkan model Snowball Throwing. Kompetensi dasar menganalisis sistem pemerintahan, sosial, ekonomi, dan kebudayaan masyarakat Indonesia pada masa kerajaan-kerajaan besar Islam di Indonesia yang berpengaruh pada kehidupan masyarakat Indonesia masa kini dan materi pelajaran menganalisis kehidupan sosial, ekonomi pada masa Kerajaan Islam di Indonesia.

Berdasarkan aktifitas siswa yang diamati sesuai dengan keterlibatan siswa selama proses pembelajaran pada pertemuan kedua siklus I di atas, sebagai berikut:

a. Keaktifan siswa mendengarkan penjelasan guru $84 \%$, berpredikat baik, sehingga perlu ditingkatkan.

b. Keaktifan siswa aktif dalam pembelajaran $94 \%$ dan bekerjasama dengan baik dalam kegiatan kelompok 94\%, keduanya berpredikat amat baik, sehingga perlu dipertahankan dan ditingkatkan.

c. Keaktifan peserta berani mengemukakan pendapat $74 \%$, dan merespon pertanyaan dari guru $71 \%$, keduanya berpredikat cukup, sehingga perlu ditingkatkan dan motivasi.

Hasil uji kompetensi dengan penetapan Kriteria Ketuntasan Minimal (KKM) 75 pada pertemuan kedua siklus II yang diikuti oleh 31 siswa ternyata hasilnya masih perlu ditingkatkan karena yang tidak tuntas ada 6 siswa dan 25 siswa tuntas, sehingga ketuntasan belajar siswa pada pertemuan kedua siklus II adalah $81 \%$ dengan rata-rata nilai kelas 93,23. Dengan demikian meskipun sudah ada peningkatan $34 \%$ dari pertemuan pertama siklus II tetap masih perlu adanya suatu tindakan untuk meningkatkan ketuntasan atau prestasi belajar.

Berdasarkan perbandingan data keaktifan siswa maupan nilai atau prestasi membuktikan adanya peningkatan yang segnifikan. Dengan demikian meskipun sudah ada peningkatan $34 \%$ dari pertemuan pertama siklus II tetap masih perlu adanya suatu tindakan untuk meningkatkan ketuntasan atau prestasi belajar.

Tabel 1: Distribusi Nilai Sejarah secara Individu

\begin{tabular}{|c|c|c|c|c|c|}
\hline \multirow{2}{*}{ No } & \multirow{2}{*}{ Nilai } & \multicolumn{2}{|c|}{ Siklus I } & \multicolumn{2}{c|}{ Siklus II } \\
\cline { 3 - 6 } & & P-1 & P-2 & P-1 & P-2 \\
\hline 1 & $0.00-74.00$ & 29 & 14 & 17 & 6 \\
\hline 2 & $75.00-80.00$ & 3 & 12 & 11 & 16 \\
\hline 3 & $81.00-90.00$ & 1 & 4 & 4 & 5 \\
\hline 4 & $91.00-100.00$ & 0 & 1 & 0 & 4 \\
\hline \multicolumn{2}{|c|}{ Jumlah Peserta Didik } & 33 & 31 & 32 & 31 \\
\hline
\end{tabular}

Tabel 2: Perbedaan hasil penilaian Sejarah Siklus I dan Siklus II

\begin{tabular}{|c|c|c|c|c|c|c|c|}
\hline \multirow{2}{*}{$\begin{array}{c}\text { Siklus } \\
\text { ke- }\end{array}$} & \multirow{2}{*}{$\begin{array}{l}\text { Pertem } \\
\text { uan ke }\end{array}$} & \multirow{2}{*}{$\begin{array}{c}\text { Jml } \\
\text { Siswa }\end{array}$} & \multicolumn{2}{|c|}{ Nilai Tuntas } & \multirow{2}{*}{ Nilai } & \multirow{2}{*}{$\begin{array}{c}\% \\
\text { Ketercapai } \\
\text { an }\end{array}$} & \multirow{2}{*}{$\begin{array}{c}\% \\
\text { Pening } \\
\text { katan }\end{array}$} \\
\hline & & & Tidak & Tuntas & & & \\
\hline \multirow{2}{*}{$\begin{array}{c}\text { Siklus } \\
1\end{array}$} & 1 & 33 & 29 & 4 & $\begin{array}{c}76,6 \\
7\end{array}$ & $12 \%$ & \multirow{2}{*}{$43 \%$} \\
\hline & 2 & 31 & 14 & 17 & $\begin{array}{c}87,1 \\
0\end{array}$ & $55 \%$ & \\
\hline \multirow{2}{*}{$\begin{array}{c}\text { Siklus } \\
2\end{array}$} & 1 & 32 & 17 & 15 & $\begin{array}{c}83,7 \\
5\end{array}$ & $47 \%$ & \multirow{2}{*}{$34 \%$} \\
\hline & 2 & 31 & 6 & 25 & $\begin{array}{c}93,2 \\
3\end{array}$ & $81 \%$ & \\
\hline
\end{tabular}

Keterangan:

Jumlah siswa kelas XI IIS-2 ada 36 orang tetapi pada saat pengambilan data ada beberapa siswayang tidak hadir.

\section{KESIMPULAN}

Berdasarkan hasil penelitian tindakan kelas yang dilaksanakan oleh 
peneliti dan kolaborator dapat disimpulkan bahwa implementasi model Snowball Throwing dapat meningkatkan prestasi nilai mata pelajaran Sejarah siswa kelas XI IIS-2 SMA Muhammadiyah 2 Yogyakarta. Peningkatan prestasi nilai mata pelajaran Sejarah dapat dilihat sebagai berikut:

1. Implementasi model Snowball Throwing dalam proses pembelajaran di kelas XI IIS-2 SMA Muhammadiyah 2 Yogyakarta terlihat lebih kondusif, menyenangkan, menarik dan dapat menambah semangat belajar serta siswa lebih antusias mengikuti pembelajaran mata pelajaran Sejarah.

2. Implementasi model Snowball Throwing terbukti dapat meningkatkan prestasi nilai hasil belajar siswa kelas XI IIS-2 SMA Muhammadiyah 2 Yogyakarta. Prestasi nilai hasil belajar pada siklus 1 antara pertemuan pertama dan pertemuan kedua menujukkan peningkatan $43 \%$. Sedangkan pada siklus 2 antara pertemuan pertama dan pertemuan kedua menujukkan peningkatan $34 \%$.

3. Berdasarkan hasil pengisian angket yang diberikan kepada siswa memberikan jawaban $100 \%$ menyukai model pembelajaran Snowball Throwing diterapkan oleh guru dalam proses pembelajaran mata pelajaran Sejarah.

\section{DAFTAR PUSTAKA}

Arikunto, Suharsimi. 2012. Penelitian

Tindakan Kelas. Jakarta : Bumi Aksara.

Hamalik, Oemar. 2011. Kurikulum Dan Pembelajaran. Jakarta: Bumi Aksara.

Riduwan. 2010. Metode Dan Teknik Menyusun Tesis. Bandung: Alfabeta.
Slamet. 2003. Belajar dan faktor-faktor yang memepngaruhinya. Jakarta : Rineka Cipta.

Solihatin, Etin dan Raharjo. 2008. Cooperative Learning Analisis Model Pembelajaran IPS. Jakarta: Bumi Aksara.

Sugiyono. 2010. Metode Penelitian Pendidikan Pendekatan Kuantitatif, Kualitatif, dan $R$ \& $D$. Bandung: Alfabeta.

Suprijono, Agus. 2014. Cooperative Learning Teori \& Aplikasi Paikem. Yogyakarta: Pustaka Pelajar.

\section{http://definisi-atau-pengertian-hasil- \\ belajar-menurut-para-ahli/}

http://pinterdw.blogspot.com/2012/03/p engertian-minat-belajar.html 